\title{
PENILAIAN RISIKO KESEHATAN KERJA PADA PENGGUNAAN PESTISIDA DENGAN METODE (HIRAC) DI PERKEBUNAN SAWIT SUMATERA SELATAN INDONESIA
}

\author{
Maksuk $^{1}$ \\ ${ }^{1}$ Jurusan Keperawatan, Poltekkes Kemenkes Palembang, Indonesia: \\ maksuk@poltekkespalembang.ac.id \\ (Korespondensi e-mail: maksuk@poltekkespalembang.ac.id)
}

\begin{abstract}
ABSTRAK
Seiring dengan meningkatnya perkebunan kelapa sawit, keterlibatan jumlah pekerja di sektor ini juga meningkat demikian pula kontak pekerja terhadap berbagai bahan aktif pestisida. Penelitian ini bertujuan untuk menilai risiko yang terlibat dalam penerapan pestisida di perkebunan kelapa sawit. Kajian ini merupakan kajian observasional dengan menggunakan metode Hazard Identification Risk Assessment Control (HIRAC). Pengendalian risiko didasarkan pada skala risiko melalui pengendalian administratif dan penggunaan peralatan pelindung diri sesuai dengan standar dan penyediaan situs khusus untuk dekontaminasi setelah penerapan pestisida. Kesimpulan: metode pengendalian bahaya identifikasi risiko (HIRAC) adalah salah satu metode yang digunakan untuk menilai risiko kesehatan pekerja yang berkontribusi pada sistem manajemen kesehatan dan keselamatan kerja (SMK3), khususnya untuk menilai risiko kesehatan pekerja. Oleh karena itu, metode ini perlu dikembangkan sebagai metode untuk menilai risiko kesehatan pekerja dalam proses penerapan pestisida di perkebunan kelapa sawit.
\end{abstract}

Kata kunci: Penilaian risiko, Perkebunan kelapa sawit, Aplikasi pestisida, Pekerja

\section{Abstract}

The use of pesticides is now more widely used especially in agricultural and plantation areas including oil palm plantations. Along with the increase in oil palm plantations, the involvement of the number of workers in this sector has also increased. This study aims to assess the risks involved in applying pesticides in oil palm plantations. This study was an observational study using the Hazard Identification Risk Assessment Control (HIRAC) method. Health risk assessment is carried out for complaints of itchy skin, eyes, redness and cough with the results of health risk assessment obtained with a medium risk scale and high risk. Risk control is based on the scale of risk through administrative control and the use of personal protective equipment in accordance with standards and the provision of special sites for decontamination after the application of pesticides. Conclusion: The Hazard Identification Risk Assessment (HIRAC) Control Method is one of the methods used to assess workers 'health risks that contribute to Occupational Safety and Health Management Systems (SMK3), especially to assess workers' health risks. Therefore, this method needs to be developed as a method for assessing the health risks of workers in the process of applying pesticides in oil palm plantations. 


\section{PENDAHULUAN}

Penggunaan pestisida saat ini semakin luas digunakan terutama di area pertanian dan perkebunan termasuk didalamnya perkebunan sawit. Saat ini jumlah pestisida yang digunakan dan terdaftar mencapai 3.207 formulasi untuk pertanian dan perkebunan (Ditjen PSP, 2016). Perkebunan sawit merupakan salah satu komoditas yang sangat diminati saat ini, dengan meningkatnya alih fungsi lahan menjadi perkebunan kelapa sawit tentunya banyak tenaga kerja yang terlibat dalam kegiatan perkebunan tersebut.

Hasil telaah penulis terhadap luas area perkebunan sawit, luas area perkebunan kelapa sawit di Indonesia terus bertambah setiap tahunnya. Sampai dengan tahun 2015 saja, sekitar 30.948.931 Ha dalam skala Nasional, di Provinsi Sumatera Selatan sendiri setiap tahun mengalami peningkatan yang pada tahun 2015 sekitar $1.161 .043 \mathrm{Ha}$ (Dirjen Perkebunan, 2015), sedangkan di Kabupaten Banyuasin luas perkebunan sawit sekitar 141.238 Ha (Disbun Prov. Sumsel, 2013).

Seiring meningkatnya luas perkebunan sawit, maka keterlibatan jumlah tenaga kerja pada sektor tersebut juga ikut meningkat. Saat ini jumlah tenaga kerja di sektor pertanian Indonesia sebanyak 40,8 juta pekerja (ILO, 2014), jumlah tenaga kerja di perkebunan kelapa sawit Provinsi Sumatera Selatan sebanyak 205.759 pekerja dan di Kabupaten Banyuasin sebanyak 18.104 pekerja (Disbun Provinsi Sumsel, 2013). Kondisi ini menyebabkan keterlibatan pekerja dan keterpaparan pekerja dengan berbagai bahan aktif pestisida semakin meningkat.

Perusahan perkebunan kelapa sawit dan pabrik Kelapa sawit, ditutut harus menerapkan dan bersertifikat RSPO dan ISPO. Salah satu persyaratan RSPO dan ISPO adalah harus ada penerapan Sistem Manajemen Keselamatan dan Kesehatan Kerja (SMK3). Namun dari beberapa penelitian yang telah dilakukan oleh penelitian sebelumnya masih memfokuskan pada SMK3 di pabrik kelapa sawit. Dari penelitian yang dilakukan di pabrik sawit PT. Rama Bakti Estate lebih difokuskan pada kecelakaan kerja karyawan (Gunawan \& Andri, 2016).

Penelitian yang dilakukan di pabrik sawit PT. Stelindo Wahana Perkasa Belitung Timur lebih memfokuskan pada keselamatan pekerja di pabrik sawit (Sintorini, dkk, 2016). Selain itu penelitian yang dilakukan di PT. Waru Kaltim Plantation juga hanya memfokuskan pada kecelakaan pekerja (Ratna Sari, 2013). Di perkebunan sawit PT. MUL dilkukan analisis potensi bahaya dan pengendaliannya menggunakan metode HIRAC tetapi difokuskan pada kecelakaan kerja di industri sawit Mamuju Sulawesi Barat (Malapiang \& Samosir, 2014).

Keselamatan dan kesehatan kerja merupakan hal yang sangat penting diterapkan di setiap institusi baik milik pemerintah maupun swasta termasuk diantaranya adalah perkebunan sawit. Metode HIRAC merupakan salah satu cara yang dapat digunakan dalam Sistem Majemen Keselamatan dan Kesehatan Kerja (SMK3). Oleh karena itu penelitian ini bertujuan untuk penilaian risiko kesehatan kerja di perkebunan sawit menggunakan metode HIRAC.

\section{METODE}

\section{Jenis Penelitian}

Jenis penelitian yang digunakan adalah deskriptif dengan metode yang digunakan yaitu Hazard Identification Risk Assessment Control (HIRAC) meliputi tahap identifikasi hazard, penilaian risiko dan pengendalian risiko (AS/NZS 4360, 2004).

\section{Lokasi dan Waktu Penelitian}

Penelitian ini dilakukan di Perkebunan Sawit PT. S Kabupaten Banyuasin. Penelitian dilaksanakan pada bulan Februari 2017.

\section{Populasi dan Sampel}


Populasi penelitian adalah seluruh pekerja di perkebunan sawit yang terpapar pestisida dan terdiri dari penyemprot, pengawas dan manager. Sampel dalam penelitian ini sebanyak 60 pekerja.

\section{Pengumpulan Data}

Pengumpulan data dilakukan dengan melalui wawancara pada pekerja menggunakan check list dan metode HIRAC.

\section{Pengolahan dan Analisis Data}

Pengolahan data dilakukan menggunakan perangkat lunak komputer. Analisis data dilakukan dengan cara univariat dan disajikan dalam bentuk tabel dan grafik.

\section{HASIL}

Penyusunan HIRARC dimulai dengan melakukan hazard identification pada seluruh area perkebunan sawit PT. S. Potensi bahaya yang ditemukan pada tahap identifikasi hazard akan dianalisa dan dilakukan risk assessment untuk mengetahui tingkat risikonya. Hasil dari risk assessment yang telah dilakukan akan dijadikan dasar untuk melakukan risk control.

Tahap awal yang dilakukan dalam identifkasi hazard yaitu dengan mengidentifikasi jenis bahan aktif pestisida yang digunakan untuk penyemprotan di area perkebunan sawit. Hasil identifikasi bahan aktif pestisida tersebut dijelaskan pada tabel berikut. Tebel tersebut berisi informasi pestisida yang digunakan pada PT. S dan bahan aktif yang dikandung.

Tabel 1. Identifikasi Bahan Aktif Pestisida yang Digunakan di Perkebunan Sawit PT. S

\begin{tabular}{ccl}
\multicolumn{3}{c}{ Kabupaten Banyuasin } \\
\hline No & $\begin{array}{c}\text { Nama } \\
\text { Dagang }\end{array}$ & $\begin{array}{l}\text { Formulasi/ } \\
\text { Bahan aktif }\end{array}$ \\
\hline 1 & Gramoxone & $\begin{array}{l}\text { Paraquat } \\
\text { diklorida } \\
\text { (ion paraquat) }\end{array}$ \\
& & Glifosat \\
2 & Roundup & Metil \\
3 & Biofuran & metsulfuron
\end{tabular}

\begin{tabular}{lll}
4 & Sinergy & $\begin{array}{l}\text { Difenokonazol } \\
\text { Propikonazol }\end{array}$ \\
5 & Dithane & Mankozeb \\
6 & Cymbush & Sipermetrin \\
7 & Marshal & Karbosulfan \\
8 & Matador & Lamda sihalotrin \\
\hline
\end{tabular}

Selanjutnya wawancara pada pekerja dilakukan terkait Program Kesehatan dan Keselamatan Kerja (K3) dan keluhan yang dialami pekerja selama melakukan aktivitas penyemprotan pestisida di perkebunan sawit PT. S Kabupaten Banyuasin

Tabel 2. Program K3 di Perkebunan Sawit PT. S Kabuapaten Banyuasin

\begin{tabular}{cccc}
\hline No & Program K3 & Jumlah & $\begin{array}{c}\text { Persen } \\
(\%)\end{array}$ \\
\hline 1 & \multicolumn{1}{c}{ Kelengkapan } \\
& APD & & \\
& $-\quad$ Tidak & 35 & 58,3 \\
& $\quad$ lengkap \\
& $-\quad$ Lengkap & 25 & 41,7 \\
2 & $\begin{array}{l}\text { Dekontaminasi } \\
\text { setelah terpapar } \\
\text { pestisida }\end{array}$ & & \\
& $-\quad$ Tidak & 46 & 76,7 \\
& $-\quad$ Ya & 14 & 23,3 \\
\hline
\end{tabular}

Berdasarkan Tabel 2 dijelaskan bahwa program K3 dilihat dari kelengkapan penggunaan alat pelindung diri dan dekontaminasi setelah terpapar pestisida. Sedangkan yang melakukannya hanya 14 orang.

Gambar 1. Persentase Keluhan Pekerja di Perkebunan Sawit PT. S (n=60)

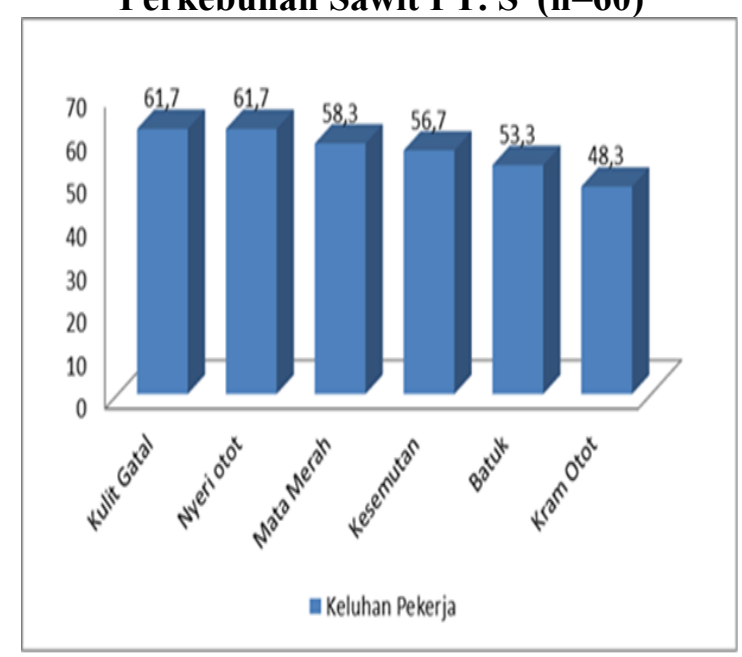


Berdasarkan Gambar 1 dijelasakan bahwa dari 60 pekerja dijelaskan bahwa keluhan yang paling banyak adalah kulit gatal dan nyeri otot masing - masing sebanyak $61,7 \%$.

Tabel 3. Identifikasi Hazard Selama Proses Aplikasi Pestisida di Perkebunan Sawit PT. S Kabupaten Banyuasin

\begin{tabular}{|c|c|}
\hline $\begin{array}{l}\text { Faktor } \\
\text { Bahaya }\end{array}$ & Bahaya yang Muncul \\
\hline $\begin{array}{l}\text { Manusia } \\
(\text { Man })\end{array}$ & $\begin{array}{l}\text { Ketidakpatuhan pekerja dalam } \\
\text { menggunakan pelindung diri } \\
\text { seperti: masker, sarung, tangan } \\
\text { dan pelindung muka, pekerja tidak } \\
\text { melakukan dekontaminasi setelah } \\
\text { terpapar pestisida. }\end{array}$ \\
\hline Material & $\begin{array}{l}\text { Droplet pestisida yang } \\
\text { disemprotkan dapat menyebabkan }\end{array}$ \\
\hline
\end{tabular}

batuk, kulit gatal, mata merah, bagi pekerja jika dihirup dan yang masuk melalui kulit, bekas wadah pestisida yang dibuang kelingkungan dapat mencemari lingkungan.

Sarana Tidak tersedianya ruang khusus untuk dekontaminasi setelah terpapar pestisida menyebabkan pestisida dapat diserap oleh tubuh pekerja melalui kulit.

Table di atas menjelaskan faktorfaktor bahaya yang didapatkan dari hasil pengkajian pada perkebunan sawit PT. S. Faktor tersebut adalah manusia, material, dan sarana. Analisis faktor-faktor tersebut sangat penting untuk dilakukan.

Tabel 4. Penilaian Risiko Selama Proses Aplikasi Pestisida di Perkebunan Sawit PT. S Kabupaten Banyuasin

\begin{tabular}{llcccc}
\hline \multicolumn{1}{c}{ Sumber Bahaya } & Potensi Bahaya & $\begin{array}{c}\text { Risiko } \\
\text { Kesehatan }\end{array}$ & Probability & Severity & Keterangan \\
\hline $\begin{array}{l}\text { Pekerja tidak lengkap } \\
\text { menggunakan }\end{array}$ & $\begin{array}{l}\text { Droplet bahan aktif } \\
\text { pestisida yang } \\
\text { APD }\end{array}$ & $\begin{array}{c}\text { Mata Merah } \\
\text { Batuk }\end{array}$ & 3 & 2 & $\begin{array}{l}\text { Moderate } \\
\text { Risk }\end{array}$ \\
$\begin{array}{l}\text { terhirup pekerja } \\
\text { Pekerja tidak melakukan } \\
\text { dekontaminasi setelah } \\
\text { terpapar pestisida }\end{array}$ & $\begin{array}{l}\text { Sisa - sisa pestisida } \\
\text { yang menempel } \\
\text { pada tubuh pekerja }\end{array}$ & $\begin{array}{l}\text { Kulit Gatal, } \\
\text { kemerahan }\end{array}$ & 5 & 2 & High Risk \\
\hline
\end{tabular}

Droplet bahan aktif pestisida yang disemprotkan terhirup pekerja dapat menyebabkan mata merah dan batuk, pengendalian risiko saat ini yaitu hanya penggunaan masker. Namun masker yang digunkan hanya masker biasa dan belum mampu mengurangi masuknya bahan aktif pestisida yang terhirup pekerja. Oleh karena itu nilai yang diberikan nilai probability yang diberikan 3 (hanya sekali-sekali dialami pekerja) dan nilai severity diberikan 2 karena pekerja masih bisa menangani sendiri. Sedangkan kulit gatal, kemerahan paling sering dialami pekerja sehingga diberikan nilai probability 5, akan tetapi masih bisa ditangani pekerja sendiri sehingga nilai severity diberikan nilai 2 .

Tabel 5. Pengendalian Risiko Selama Proses Aplikasi Pestisida di Perkebunan Sawit PT. S Kabupaten Banyuasin

\begin{tabular}{llll}
\hline \multicolumn{1}{c}{$\begin{array}{c}\text { Skala } \\
\text { Risiko }\end{array}$} & \multicolumn{1}{c}{ Potensi Bahaya } & Risiko & \multicolumn{1}{c}{ Pengendalian Risiko } \\
Bahaya & & Kesehatan & \\
\hline $\begin{array}{l}\text { Moderate } \\
\text { Risk }\end{array}$ & Droplet bahan aktif & Mata Merah & Pemberian sanksi \\
& $\begin{array}{l}\text { pestisida yang } \\
\text { disemprotkan terhirup } \\
\text { pekerja }\end{array}$ & Batuk & $\begin{array}{l}\text { kepada pekerja yang tidak } \\
\text { menggunakan APD, Penyediaan APD }\end{array}$ \\
& & $\begin{array}{l}\text { sesuai standar, sosialisasi pentingnya } \\
\text { budaya K3. }\end{array}$
\end{tabular}



High Risk $\quad$ Sisa - sisa pestisida yang menempel pada tubuh pekerja

Kulit Gatal, Penyediaan ruang khusus untuk kemerahan dekontaminasi setelah terpapar pestisida
Berdasarkan wawancara dengan pekerja PT. S diketahui bahwa belum tersedianya APD yang sesuai standar dan belum ada pengawasan serta pemberian sanksi kepada pekerja yang tidak menggunakan APD, dengan pemberian sanksi berupa denda atau peringatan keras dari atasan diharapkan dapat mengurangi pekerja yang tidak menggunakan APD.

Sosialisasi pentingnya K3 dapat dilakukan melalui pemasangan banner slogan K3 ditempat-tempat yang mudah dilihat oleh pekerja serta menggunakan katakata atau gambar yang sederhana agar mudah dimengerti oleh pekerja.

\section{PEMBAHASAN}

Saat ini, lebih dari $30 \%$ populasi dunia bergantung pada pertanian untuk penghidupannya. Banyak negara pertanian, terutama di Asia Tenggara, mengalami intensifikasi yang cepat dari produksi pertanian dan peternakan, yang secara kritis dapat mempengaruhi ekosistem dan kesehatan manusia. Pertanian adalah salah satu pekerjaan yang paling rentan terhadap berbagai bahaya. Hal ini juga terkait dengan tingkat tertinggi dari kesehatan yang merugikan setiap tahun di seluruh dunia. Pekerja pertanian telah terbukti terkena berbagai bahaya kimia, seperti pestisida dan zat kimia lainnya. Seorang pekerja pertanian kemungkinan terpapar secara simultan atau berurutan terhadap berbagai bahaya pekerjaan, dengan berbagai rute paparan, dari berbagai sumber dan selama periode waktu yang berbeda. Demikian pula, penyakit akibat kerja atau gangguan kesehatan mungkin sering disebabkan oleh paparan berbagai faktor risiko (Bertin, Bodin, Fouquet, Bonvallot, \& Roquelaure, 2018; Nguyen et al., 2018; White \& Cessna, 1989).
Identifikasi hazard yang dilakukan di perkebunan sawit PT. S Kabupaten Banyuasin difokuskan pada penggunaan pestisida selama aplikasi penyemprotan. Dari hasil identifikasi bahan aktif pestisida ada beberapa bahan aktif pestisida yang digunakan untuk melakukan aplikasi di area perkebunan sawit.

Kondisi ini jika tidak diawasi dengan ketat dapat membahayakan kesehatan pekerja. Hal ini menyebabkan keterpaparan pekerja terhadap paraquat cukup tinggi terutama pada penyemprot dan pengawas selama penyemprotan di area perkebunan (Djojosumarto, 2008).

Dalam beberapa tahun terakhir, penggunaan produk kimia yang lebih aman dan berkelanjutan di bidang pertanian telah menjadi penting di seluruh dunia. Di Uni Eropa tujuan ini diwakili oleh implementasi kebijakan Integrated Pest Management (IPM), yaitu serangkaian intervensi legislatif mulai dari masalah Directive 2009/128 / EC, membangun kerangka kerja untuk masyarakat mencapai penggunaan pestisida yang berkelanjutan antara lain, persyaratan keamanan mesin untuk aplikasi pestisida, penempatan produk perlindungan tanaman di pasar, klasifikasi, pelabelan, dan pengemasan zat dan campuran, dan persyaratan untuk pendaftaran, evaluasi, otorisasi, dan pembatasan bahan kimia, memiliki dampak besar pada Pekerja, dan perusahaan yang beroperasi di sektor pertanian.(Handford, Elliott, \& Campbell, 2015; Lamichhane, 2017; Machado \& Martins, 2018).

Dalam kasus pestisida, paparan tergantung pada banyak faktor dan pekerja yang melakukan pekerjaan yang sama kemungkinan terpapar dengan berbagai tingkat zat aktif. Masih kurangnya bukti tentang bagaimana tingkat dosis atau paparan berulang dapat mempengaruhi 
kesehatan pekerja. Meskipun ada beberapa basis data paparan pestisida, tetapi belum mendapatkan data yang mendalam, sehingga pentingnya penilaian risiko awal, yang akan memberikan informasi tentang hubungan antara penggunaan pestisida dan risiko paparan yang berakibat bagi pekerja, sehingga menjadi tugas yang kompleks dan peru terus diakukan secara berkesinambungan (Bertin et al., 2018; Coble et al., 2011; Kim, Kabir, \& Jahan, 2017; Lewis, Tzilivakis, Warner, \& Green, 2016).

Pekerja dapat terpapar berbagai jenis bahaya pekerjaan pada saat yang sama, berpotensi meningkatkan risiko hasil kesehatan yang merugikan. Beberapa penelitian telah mengeksplorasi dampak dari banyak paparan pekerjaan terhadap kesehatan pekerja pertanian. Sejumlah studi yang sangat terbatas telah menyelidiki efek koeksposisi antara bahaya biomekanik, fisik, dan kimia terhadap kesehatan kerja (Bertin et al., 2018; Nguyen et al., 2018).

Keluhan yang dialami pekerja akibat paparan pestisida diantaranya mata merah, batuk dan kulit gatal, apabila berlangsung dalam jangka waktu yang lama (long term exposure) dapat menyebabkan terjadinya penyakit akibat pekerja. Studi yang dilaporkan pada pekerja wanita sebelum menyemprot pestisida gejala mata merah sebanyak $14,9 \%$, dan setelah menyemprot sebanyak 24,2\% (Murphy, 1999). Ini menunjukkan terjadi peningkatan gejala mata merah sebelum dan setelah penyemprotan.

Pekerja yang terkena percikan saat aplikasi pestisida paraquat pada mata sebanyak $42 \%$ (Castro-Gutierrez et al., 1997). Selain itu kontak mata dengan larutan pestisida paraquat menyebabkan inflamasi kornea (Bismuth et al.,1995). Pada petani padi yang mengalami iritasi mata sebanyak 42,9\% (Sapbamrer \& Nata, 2014). Hal ini disebabkan kecerobohan pekerja dalam melakukan aplikasi pestisida di lapangan sehingga dapat menimbulkan cidera. Paparan kulit dialami pekerja sekitar 95\%, untuk pencampur/pengaduk sebanyak $86 \%$ terpapar di tangan dan pada penyemprot sekitar 90\% terpapar di tangan, kaki dan telapak kaki, hal ini berhubungan dengan perlengkapan pelindung diri dan lingkungan (Blanco et al., 2005).

Perlunya evaluasi paparan toksisitas membutuhkan peringkat sintesis tingkat toksisitas dalam nilai numerik. Seperti yang diamati oleh Maroni et al., meskipun bersifat kualitatif, penggunaan informasi yang diberikan untuk penilaian risiko awal dalam konteks K3 dapat dianggap efektif. masalah penyediaan alat yang memungkinkan estimasi risiko paparan pestisida, berkontribusi terhadap definisi batas dari paparan dan pencegahan efek toksik pada pekerja. Fakta, penilaian risiko yang terkait dengan paparan pestisida menghadirkan banyak variabel, menjadikannya tugas yang lebih kompleks daripada ketika berhadapan dengan jenis bahaya lain yang dihadapi pekerja pertanian (Bertin et al., 2018; Bevan et al., 2017; Maroni, Fait, \& Colosio, 1999).

Pada pekerjaan yang menggunakan variasi bahan aktif pestisida yang banyak sebaiknya menggunakan APD yang sesuai dengan seluruh material bahan kimia dan kesalahan dalam melakukan cuci tangan dapat menjadi salah satu penyebab sisa bahan aktif paraquat menempel pada permukaan kulit pekerja dan mengeringkan tangan setelah dicuci dapat berperan dalam mencegah semakin parahnya kondisi kulit karena tangan yang lembab (WHO, 2005).

Beberapa Bahaya pengunaan dari pestisida terhadap pekerja adalah ; Menyebabkan gangguan mata berat: Dapat menyebabkan iritasi pernapasan; Menyebabkan iritasi kulit; Pemaparan berulang dapat menyebabkan kulit kering atau pecah-pecah; Berbahaya jika terhirup; Berbahaya ketika bersentuhan dengan kulit; Beracun jika tertelan; Menyebabkan luka bakar kulit yang parah dan kerusakan mata; Beracun jika terhirup; Toksik jika terkena kulit; Dapat menyebabkan reaksi alergi pada kulit; Dapat menyebabkan kantuk atau pusing; Dapat menyebabkan gejala alergi 
atau asma atau kesulitan bernapas jika terhirup; dll (Colosio et al., 2012; Handford et al., 2015; Lewis et al., 2016)

Penggunaan pestisida yang tidak aman dan tidak diskriminatif dalam pertanian merupakan bahaya besar bagi lingkungan dan kesehatan manusia. Dalam peneitian Jallow 2017; menilai tingkat pengetahuan, sikap dan praktik para petani Kuwait mengenai keamanan penggunaan pestisida. Sebanyak 250 petani mayoritas petani mengakui bahwa pestisida berbahaya bagi kesehatan mereka (71\%) dan lingkungan (65\%). Namun, tingkat pengetahuan petani tentang keamanan pestisida tidak memadai. Lebih dari $70 \%$ petani tidak membaca atau mengikuti instruksi label pestisida, dan 58\% tidak menggunakan alat pelindung diri (APD) saat menangani pestisida. Petani berpendidikan secara signifikan cenderung menggunakan APD dibandingkan dengan petani dengan pendidikan formal terbatas $\left(\left({ }^{2}\right.\right.$ =9,89, $\mathrm{p}<0.05$ ). (Jallow, Awadh, Albaho, Devi, \& Thomas, 2017).

Penyimpanan pestisida di dalam ruang terbuka dilaporkan $20 \%$ petani. Saat membuang limbah pestisida, responden mengadopsi praktik yang tidak aman seperti membuang, membakar, atau mengubur wadah pestisida kosong di pertanian, atau menggunakan kembali wadah tersebut. Petani juga melaporkan membuang larutan pestisida sisa atau stok pestisida lama di pertanian atau di saluran pembuangan. Sejumlah besar $(82 \%)$ petani melaporkan setidaknya satu gejala keracunan pestisida akut. Meskipun pengetahuan petani tentang bahaya pestisida tinggi, langkah-langkah keamanan yang dilaporkan buruk. Diperlukan langkah intervensi komprehensif untuk mengurangi risiko kesehatan dan lingkungan dari pestisida, termasuk program pelatihan keamanan pestisida, penegakan hukum pestisida yang ketat, dan mempromosikan pengelolaan hama terpadu dan metode pengendalian hama non-sintetis (Bevan et al., 2017; Coble et al., 2011; Colosio et al., 2012; Jallow et al., 2017; Kim et al., 2017).
Penilaian risiko di perkebunan sawit lebih difokuskan pada penilaian risiko kesehatan pekerja. Hal ini berbeda pada studi yang dilakukan di perkebunan sawit PT. MUL dilakukan analisis potensi bahaya dan pengendaliannya menggunakan metode HIRAC tetapi difokuskan pada kecelakaan kerja di industri sawit Mamuju Sulawesi Barat (Malapiang \& Samosir, 2014). Penerapan menajemen risiko ini juga telah dilakukan di pabrik pengolahan sawit PTPN IV Pebatu (Hijriani dkk, 2015). Penilaian risiko kesehatan pada pekerja juga pernah dilakukan di perkebunan sawit Kabupaten Banyuasin menggunakan metode analisis risiko kesehatan lingkungan dimana ditemukan konsentrasi pestisida paraquat diudara ditemukan sebesar $0,0125 \mathrm{mg} / \mathrm{m} 3$ (Maksuk et al. 2018). Konsentrasi pestisida paraquat di udara ini dapat menyebabkan dropletnya terhirup oleh pekerja dan lama kelamaan terakumulasi dalam paru-paru pekerja. Selain itu sisa pestisida yang disemprotkan menempel pada kulit pekerja yang tidak terlindungi mengakibatkan pestisida masuk melalui kulit pekerja.

Dari sudut pandang penilaian risiko, persyaratan yang harus dihadapi perusahaan adalah : Berikan laporan penilaian risiko yang terdokumentasi, yang menunjukkan bahwa pengusaha telah memperhitungkan semua risiko yang berasal dari penggunaan pestisida; Penilaian risiko kegiatan yang terkait dengan penggunaan pestisida harus mempertimbangkan situasi paparan terburuk untuk setiap kegiatan; Semua fase proses harus dipertimbangkan, mulai dari penanganan, persiapan campuran, pengaturan peralatan aplikasi, pencampuran, pemuatan, dan aplikasi, hingga operasi akhir terkait dengan pembersihan dan pemeliharaan peralatan, serta berurusan dengan pengelolaan air pembersih dan residu pestisida; Penilaian risiko harus mempertimbangkan sifat-sifat berbahaya dari pestisida, informasi tentang kesehatan dan keselamatan yang diberikan oleh lembar keselamatan setiap produk, tingkat paparan, dan durasi paparan, serta nilai batas pajanan pekerjaan apa pun. atau nilai batas biologis 
yang terkait dengan setiap produk; Tindakan pencegahan dan perlindungan yang diterapkan, serta periode keselamatan masuk kembali untuk setiap jenis aplikasi harus ditentukan (Handford et al., 2015; Lewis et al., 2016)

Pengendalian risiko merupakan hal yang penting dilakukan untuk memberikan rekomendasi terkait hirarki pengendalian risiko di tempat kerja. Berdasarkan hasil penelitian pengendalian risiko yang dapat dilakukan berdasarkan hasil penilaian risiko yaitu pengendalian administrasi dan penggunaan alat pelindung diri selama aplikasi pestisida di tempat kerja.

Selain itu sarana khusus untuk melakukan dekontaminasi setelah terpapar pestisida juga harus ada di area perkebunan sawit. Hal ini untuk mencegah masuknya sisa-sisa pestisida kedalam tubuh pekerja.

\section{KESIMPULAN DAN SARAN}

Hazard Identification Risk Assessment Control (HIRAC) merupakan salah satu metode yang digunakan untuk menilai paparan pestisida selama proses aplikasi di perkebunan sawit terkait risiko kesehatan pekerja. Oleh karena itu metode HIRAC perlu dikembangkan untuk memberikan kontribusi dalam Sistem Manajemen Keselamatan dan Kesehatan Kerja (SMK3) terutama dalam menilai risiko kesehatan pekerja

\section{DAFTAR PUSTAKA}

AS/NZS 4360. (2004). Astralian Standar/New Zealand Standard For Risk Management. (http://www.epsonet.) di akses 20 Maret 2016.

Bismuth C, Hall A, and Wong A, (1995). Paraquat ingestion exposure: symptomatology and risk, In: Bismuth $\mathrm{C}$, and Hall AH (eds), Paraquat poisoning: mechanisms, prevention, treatment, 195-210, New York: Marcel Dekker.

Blanco LE, Aragn A, Lundberg I, Liden C, Wesseling C, and Nise G, 2005. Determinants of dermal exposure among Nicaraguan subsistence farmers during pesticide applications with backpack sprayers, Annals of Occupational Hygiene, 49(1), 17-24.

Bertin, M., Bodin, J., Fouquet, N., Bonvallot, N., \& Roquelaure, Y. (2018). Multiple exposures and coexposures to occupational hazards among agricultural workers: A systematic review of observational studies. Safety and health at work, 9(3), 239-248.

Bevan, R., Brown, T., Matthies, F., Sams, C., Jones, K., Hanlon, J., \& La Vedrine, M. (2017). Human biomonitoring data collection from occupational exposure to pesticides. EFSA Supporting Publications, 14(3), 1185E.

Coble, J., Thomas, K. W., Hines, C. J., Hoppin, J. A., Dosemeci, M., Curwin, B., . . . Sandler, D. P. (2011). An updated algorithm for estimation of pesticide exposure intensity in the agricultural health study. International journal of environmental research and public health, 8(12), 4608-4622.

Colosio, C., Rubino, F. M., Alegakis, A., Ariano, E., Brambilla, G., Mandic-Rajcevic, S., .. . Somaruga, C. (2012). Integration of biological monitoring, environmental monitoring and computational modelling into the interpretation of pesticide exposure data: Introduction to a proposed approach. Toxicology letters, 213(1), 49-56.

Castro-Gutierrez N, McConnell R, Andersson K, Pacheco-Anton F, Hogstedt C. (1997). Respiratory symptoms, spirometry and chronic occupational paraquat exposure. Scand J Work Environ Health, 23:4217.

Dinas Perkebunan Provinsi Sumatera Selatan. (2013). Statistik Perkebunan Provinsi Sumatera Selatan.

Direktorat Jenderal Perkebunan. (2015). Statistik Perkebunan Indonesia 20132015.

Direktorat Jenderal Prasarana dan Produksi Pertanian Kementerian Pertanian RI. (2016). Pestisida Pertanian dan Kehutanan Terdaftar.

Djojosumarto. (2008). Teknik Aplikasi Pestisida Pertanian. Yogyakarta: Kanisius.

Handford, C. E., Elliott, C. T., \& Campbell, K. (2015). A review of the global pesticide legislation and the scale of challenge in reaching the global harmonization of 
food safety standards. Integrated environmental assessment and management, 11(4), 525-536.

Jallow, M. F., Awadh, D. G., Albaho, M. S., Devi, V. Y., \& Thomas, B. M. (2017). Pesticide knowledge and safety practices among farm workers in Kuwait: Results of a survey. International journal of environmental research and public health, 14(4), 340.

Kim, K.-H., Kabir, E., \& Jahan, S. A. (2017). Exposure to pesticides and the associated human health effects. Science of the Total Environment, 575, 525-535.

Lamichhane, J. R. (2017). Pesticide use and risk reduction in European farming systems with IPM: An introduction to the special issue. Crop protection, 100(97), 1-6.

Lewis, K. A., Tzilivakis, J., Warner, D. J., \& Green, A. (2016). An international database for pesticide risk assessments and management. Human and Ecological Risk Assessment: An International Journal, 22(4), 1050-1064.

Machado, S. C., \& Martins, I. (2018). Risk assessment of occupational pesticide exposure: Use of endpoints and surrogates. Regulatory Toxicology and Pharmacology, 98, 276-283.

Maroni, M., Fait, A., \& Colosio, C. (1999). Risk assessment and management of occupational exposure to pesticides. Toxicology letters, 107(1-3), 145-153.

Gunawan AC \& Andri Seno. (2016). Analisis Manajemen Keselamatan Dan Kesehatan Kerja (Studi Evaluasi Penanggulangan Kecelakaan Kerja Karyawan Pabrik Kelapa Sawit Rama Bakti Estate, Kec Tapung Hilir, Kab Kampar, Riau), Jom FISIP, 3(1) :1-16

International Labour Organization. (2014). Indonesia: Tren Sosial dan Ketenagakerjaan Agustus 2014. www.ilo.org/jakarta diakses 10 April 2015.

Hijriani J.Y., Lubis H. S. Mahyuni E. L. (2015). Penerapan Manajemen Risiko Pada Pabrik Kelapa Sawit (PKS)PTPN IV Unit Usaha Pabatu Tahun 2015 (The Application of Risk Management at PKS PTPN IV UNIT USAHAPABATU 2015) Mahyuni2, https://media.neliti.com/media/publicati ons/14561-ID-penerapan-manajemen- risiko-pada-pabrik-kelapa-sawit-pksptpn-iv-unit-usaha-pabat.pdf

Maksuk, Malaka T, Suheryanto, Umayah A. Risk Quotient of Airborne Paraquat Exposure on Workers at Palm Oil Plantation, IJPHS, 7 (2): 97-101.

Murphy H.H., Sanusi A, Dilts Russell, Djajadisastra M, Hirschhorn N, Yuliatingsih S, (1999). Health Effects of Pesticide Use Among Indonesian Women Farmers: Part I: Exposure and Acute Health Effects Journal of Agromedicine, 6(3).

Machado, S. C., \& Martins, I. (2018). Risk assessment of occupational pesticide exposure: Use of endpoints and surrogates. Regulatory Toxicology and Pharmacology, 98, 276-283.

Maroni, M., Fait, A., \& Colosio, C. (1999). Risk assessment and management of occupational exposure to pesticides. Toxicology letters, 107(1-3), 145-153.

Nguyen, T.-H.-Y., Bertin, M., Bodin, J., Fouquet, N., Bonvallot, N., \& Roquelaure, Y. (2018). Multiple Exposures and Coexposures to Occupational Hazards Among Agricultural Workers: A Systematic Review of Observational Studies. Safety and health at work, 9(3), 239-248. doi:10.1016/j.shaw.2018.04.002

White, G., \& Cessna, A. (1989). Occupational hazards of farming. Canadian Family Physician, 35, 2331.

Sintorini M.M, Silalahi M. D, Pratawijaya A. (2016). Kajian Sistem Manajemen Keselamatan dan Kesehatan Kerja Di Pabrik Kelapa Sawit Pt Stelindo Wahana Perkasa, Belitung Timur, Jurnal Teknik Lingkungan, 6(4): 95 - 100.

Ratna Sari R. (2013). Penerapan Manajemen Kesehatan Dan Keselamatan Kerja Dalam Meminimalkan Kecelakaan Kerja Pada Pt. Waru Kaltim Plantation, eJournal Administrasi Bisnis, 2013, 1 (3): 155-169.

World Health Organization. (2005). Guidelines on Hand Hygiene in Health Care (Advance Draft): A Summary. Switzerland: WHO Press.

\section{INFORMASI TAMBAHAN}

\section{Lisensi}


Hakcipta (c) 2019 Health Information : Jurnal Penelitian

artikel akses terbuka ini dapat disebarkan seluas-luasnya sesuai aturan Creative Commons Attribution-ShareAlike 4.0 International License dengan catatan tetap menyebutkan penulis dan penerbit sebagaimana mestinya.
Catatan Penerbit: Poltekkes Kemenkes Kendari menyatakan tetap netral sehubungan dengan klaim dari perspektif atau buah pikiran yang diterbitkan dan dari afiliasi institusional manapun. 